\title{
Affectivity of University Teachers: Personal, Social and Institutional Aspects
}

\author{
Karina Pacheco Dohms', Carla da Conceição Lettnin'1, Aline Rocha Mendes', \\ Juan J. M. Mosquera1, Claus D. Stobäus ${ }^{2}$ \\ ${ }^{1}$ Postgraduate Programs in Education, Pontifical Chatolic University of Rio Grande do Sul, Rio Grande do Sul, \\ Brazil \\ ${ }^{2}$ Postgraduate Program in Education and in Biomedical Gerontology, Pontifical Chatolic University of Rio \\ Grande do Sul, Rio Grande do Sul, Brazil \\ Email: stobaus@pucrs.br
}

Received 4 September 2014; revised 28 September 2014; accepted 16 October 2014

Copyright (C) 2014 by authors and Scientific Research Publishing Inc.

This work is licensed under the Creative Commons Attribution International License (CC BY).

http://creativecommons.org/licenses/by/4.0/

c) (7) Open Access

\section{Abstract}

Our research presents reports of 20 university teachers, both genders, from different cities of Rio Grande do Sul-BR, about what they think about affectivity in their teaching, aiming to clarify which aspects would be important to be developed by teachers and students, to contribute to better learning and well-being in the university environment, with interviews, analyzing their responses with qualitative technique of content analysis, described by Morais. The theoretical framework is mainly based on studies of: Gardner, Damasio, Casassus, Ekman, Goleman, with details on the development of emotions and feelings; complemented by Mosquera and Stobäus ideas, working in the Research Group Malaise and Wellness in Teaching and Affectivity: expression of feelings in Education. The analysis revealed eight categories: 1) Feelings/emotions in teaching; 2) Behavioral Expression of feelings/emotions; 3) Self-concept in the educational environment; 4) Affectivity and interpersonal relations in educational environment; 5) Affectivity and professional qualification; 6) Affectivity as facilitating/disturbing of learning; 7) Affectivity and identification with the profession; and 8) Affectivity related to Health and Education. As results we emphasize that affectivity/feelings of university teachers is, first, directed to the Personal Aspects (categories 1, 2, 3, 7), second, focused on Social Aspects (categories 4, 6, 8) and, finally, to Institutional Aspects (category 5), which in general leads to the understanding that, for the teachers interviewed, affect is very important in the educational context and depends on individual training (self) so you can be used positively in this environment as a tool for learning, and for healthy interpersonal relationships (contextualization).

\section{Keywords}

Education, Affectivity, Feelings, Emotions, Universitary Teacher 


\section{Introduction}

Currently, teaching as profession has undergone a remarkable social devaluation. There are many factors that characterize the abandonment of the profession, including: work overload beyond the period within the classroom, accumulation requirements, school violence and indiscipline, lack of material resources and working conditions, more in poorly and also in development countries. Some teachers who remain working get sick (with teacher malaise, stress, burnout), or use seeking strategies (as coping) to overcome these conditions of exhaustion, for ex. with increasing their resilience, seeking to realize their ideals.

On the other hand, studies (Gardner, 2001; Casassus, 2009; Goleman, 2012; Mora, 2013) indicate that environments permeated with affectivity can provide welfare to the whole school community (administrators, faculty, students, staff, parents and or guardians of students), ensuring a healthier environment and favoring both processes of teaching and learning.

According to Araújo (2003: p. 156), affectivity "was a generic term that gives quality to that affect, that gives meaning to all the affections we feel about ourselves and others, to life, nature, etc.”.

Casassus (2009: pp. 90-91) says that "feeling affection is prior to cognition basic human experience", meaning that are "pre-reflexive dynamics of self-constitution of the self (self)". He adds that it is possible to distinguish four affectivity levels in the following order: feeling, emotion, affect and mood. Thus, affects our ability to intervene in the action, stimulating or decreasing our empowerment, to better act or react.

This qualitative research was held in 2010 with twenty interviews with university teachers, 12 females and 8 males, from different cities of Rio Grande do Sul-BR, which answers were submitted to Content Analysis (Morais, 1998), lying eight categories related to the investigation theme. The study aimed to clarify which aspects of affectivity are important to the teachers and students, in order to contribute to better learning and well-being in the university environment.

\section{Affectivity: Perception of University Teachers}

From the analysis of the answers obtained from the interviews with teachers, eight categories were established, sorted in ascending order according to the frequency of responses: 1) Feelings/emotions in teaching; 2) Behavioral Expression of feelings/emotions; 3) Self-concept in the educational environment; 4) Affectivity in interpersonal relations in the educational environment; 5) Affectivity in professional qualification ; 6) Affectivity as facilitating/disturbing learning; 7) Affectivity for identification with the profession; and 8) Affectivity related to Health and Education.

Teachers were here called $\mathrm{D}$, followed by the number corresponding to the sequenced interviews.

The first category that emerged in the analysis of the answers to the interviews, when speaking about affectivity, was listed as category 1) Feelings/emotions in teaching, when they expressed positive and negative feelings together, such as these two statements:

Have joy when I see a motivated student, or right desperation and powerlessness to evaluate certain aspects of education in our country. (D1); Leave very happy, [...] a class, a class; devastated, why you could not achieve the goal, or because students were tired [...]. (D14).

Some of the positive feelings most often cited by teachers were: joy, empathy, love and pleasure, as in:

The feeling that I experiment is more satisfaction by my student learning by recognizing them [...] (D4); I find it easy to understand the mood of the people I live with. (D8)

Also some negative feelings were mentioned in the interviews, for example, frustration, sadness and helplessness, as in the two comments:

Very intense feeling of frustration when not pleased in any way or you do not get proper attention [...]. (D15); The educational context today is tense and demanding as the emotional control, since it requires constant challenges. Because of this, emerged many feelings: anger, doubts, sorrows. (D18)

We agree with Damasio (2012), who believes it is important to distinguish emotions from feelings, although there are authors who do not or only use the word emotion, often to deal with feelings, separating thus the component of perception, which also, according to him, may be more appropriate, as there is a consensus of those ideas in this scientific field. 
Complementing these idea, Goleman (2012) says that emotions are impulses coming from an evolutionary heritage of the human species, which lead to immediate action, responding to a given stimulus, which will prepare the body for a certain action, which means that are the responses of the person (verbal and non-verbal actions).

Damasio (2004: p. 73) explained that "the flow of mental contents provokes emotional responses that occur in the area of the body or your brain maps and eventually leading to feelings". He states that the emotions that come before feelings. According to the author (p. 78), "the thoughts that usually cause emotions appear in the mind, trigger emotions, and these lead to feelings". So it means that the feelings that are more elaborate, translate consciously emotions that are more elementary, remembering the ideas of Vygotsky (1989) and Luria (1980), who spoke in higher/superior forms in the human neurological development.

Mora (2013) complements explaining that emotions are unconscious and, in turn, the feelings are the conscious experience of an emotion. It is in understood an emotion through that feelings is generates. Then it is understood that there is some ambiguity in the feelings experienced by teachers, some moments of satisfaction and others as frustration.

It is believed that possibly the knowledge and use of emotional understanding by teachers and students would be reflected in situations of higher welfare in Education. We agree to Heller (1987: p. 15) when she says that "feeling means to be involved in something", understanding that this involvement could be positive or negative, active or reactive, direct or indirect, with an amplitude related to the degree of such involvement familiarity for the information generated. The implication is a constructive factor inherent to act, think, talk, etc.

Through action/reaction are essential for meaningful learning, given that students and teachers need to be engaged in the their educational processes, which can/must be satisfying and productive for both.

However, an implication of great intensity may be limited in its duration, because there is no society that does not seek regular, somehow, the intensity and the expression of feeling and it happens through customs and rituals, and some behaviors restrict such expression. In the sense, then, selects what is important to us and our perceptions, thoughts, actions, and may be stored in our memory together with their corresponding implications.

Yet Heller (1987) argues that the feeling is not information, but the motivation, since the expression of feelings indirectly informs or explains the feelings of others about someone.

Another category that emerged was 2) behavioral expression of feelings/emotions, with attitudes in that teachers put way to reflect their positions towards its students and education, as in the following extracts:

The way you treat students, the way you talk to them. [...] is developing an identification, an affection, that

is, day by day, with small things [...]. (D3); I need to act as a parent, as a friend to rescue the Self. (D10)

Darwin (2000), in his book released in 1872, The Expression of the Emotions in Man and Animals, puts the general principles of expressions of emotions that form the basis of his long study, explaining how did all the data collection on different continents, and describes very precisely and detailed as the expression of emotions: sadness, joy, anger, guilt, fear, among others, in both animals and humans.

According to him, the emotions constitute a heritable and adaptive system also of utmost importance in our evolutionary path as a species. He further adds that the expression of emotions can be understood as a primitive and universal language, decoded by all members of a species and little influenced by culture, which facilitates adaptation to the environment and is central to the survival of both lower animals as humans.

Mosquera \& Stobäus (2006: p. 128) defined the behavioral expression, explained that the perspective of feelings is:

Clearly manifested a reaction against a particular situation. For example, when we say or felt tenderness, began to feel hatred, was with a feeling of great excitement, in this case the word sense sets a particular reaction that occurs through the experience of the individual.

The term, as described by Ekman (2011), relates to control how they express certain emotions in different societies. The researcher investigated different cultures and observed that the general expression of emotions is universal, i.e., innate, as well as already described Darwin (2000), in the nineteenth century, although Ekman add that culture influences in control of how it demonstrates the expression (display rule), so would be the result of social learning.

Ekman (2011: p. 22) exemplifies to a survey regarding their expression of Japanese and American students, while watching scenes from surgery or accidents. The Japanese, when they were watching the scenes alone had 
the same expressions that Americans, but when accompanied by a researcher "dissimulated" negative expression with a smile, that is, "in particular innate expressions; in public subsidiaries expressions".

Again citing the reports of teachers, they can be understood as controlled expressions, as stated Ekman (2011), shaped by social control:

Sometimes I feel like getting out there and hug someone and I can not [...], then you have to, say not control, but a little disguise your level of feeling (D6); Neither expressed what I feel, sometimes I have trouble with this, but I'm so". (D13)

Stobäus \& Mosquera (2006) believe that the behavioral expression may reflect the inner world of the subject and its affectivity. Therefore, it is understood that the behavioral expression encompasses intra-and interpersonal relationships of people and possible facilities and disorders that subjects demonstrate, to express their emotions and feelings as well as to those with whom they relate. The veracity of this statement can be based primarily on self-knowledge and permanent self-education.

The new category withdrawal of speeches and analysis was named 3) Self-concept in educational environment, with references to a vital and ongoing process that occurs individually (on yourself) and interpersonal relationships with the other(s) directly in educational environment, in particular in relations with students and the teaching and learning processes.

While the subjects extol the knowledge of their feelings and affection for self-education, D17 states that they will be the basis for an approach/interact with people more human and therefore more positive and healthy:

In all shapes and human relations emotional life is important, in the educational context could not be different, to enable a more humane and critical learning. (D17)

According to Goñi \& Fernández (2009: p. 28), the self-concept is the idea that each person has of itself, referring to a cognitive and perceptual dimensions, taking into account a descriptive aspect (descriptions of what people do itself) and an evaluative aspect, as (Self)evaluation on their behaviors and qualities/defects.

Mendes, Dohms, Lettnin, Zacharias, Stobäus \& Mosquera (2012: p. 8) researched about self-image and selfesteem to understand how perception and valuation which the subject is himself , and that these two constructs are related to the way others talk about it and about what the subject himself thinks talking about it. Based on this, the authors consider that the two influence the construction of the Self, which refers to the idea that one has of herself, though it is as real as possible (self-awareness).

Based on this understanding, the authors propose the following schema, illustrating the (inter)relationship between self-concept (SC), self-image (SI) and self-esteem (SE).

(Inter)relations between self-concept, self-image and self-esteem

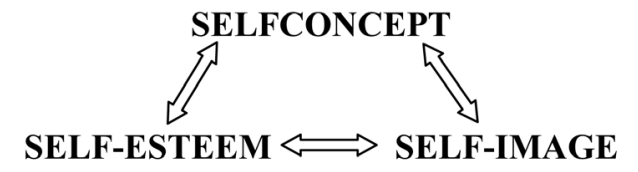

Source: Mendes, Dohms, Lettnin, Zacharias, and Stobäus Mosquera (2012: p. 8).

Stobäus (1983) points out that self-esteem will also depend on (realistic) decoding and comprehension of external situations that, in turn, inform the inner, constituting a delicate "game", in which subjects must engage more in self-knowledge and self-understanding of provoking factors and precipitants, and that dimension is closely linked to self-esteem, self-image and self-concept.

According to Schaie \& Willis (2003: p. 276), the Self is a basic element of personality and "consists of a series of knowledge structures that help the individual to give coherence to their life experiences". In this sense, the more (realistically) and the best person knows and appreciates positively, best express feelings to him/herself and to the others, which can also be seen in the statements of some of the teachers, for example:

It is a process of self-knowledge in the pursuit of self-realization, [...] because I will not be able to help my students, if I did not understand my situation. (D9); I'm learning to better cope with my feelings, trying to evolve as a human being [...]. (D20); "I consider affection as central to my life and in my quest to become more solidary and participative [...], a better person.” (D17) 
The study of Lettnin, Mendes, Dohms \& Stobäus (2013), is based on important authors like Maslow (nd, 1987) Mosquera (1978), Stobäus (1983), Rogers (1997), André \& LeLord (2000), Assisi et al. (2003), Goñi \& Fernández (2009), Sbicigo, Bandeira \& Dell’ Aglio (2010), Monteiro Azevedo, Sobreiro \& Constantino (2012), who suggests that realistic/positive self-image and self-esteem improve more the performance of the subjects in educational environment, as they add healthier and affectionate (inter)relationships.

As a way of understanding contact between people, is echo through the content of the speeches of teachers in the category, called 4) Affectivity and interpersonal relations in educational environment, as reported:

Feelings tell us as humans and are essential for good interpersonal relations [...]. Only learn in relation to the other, and this implies acceptance, empathy, identification, sense of belonging. Moll (2004) said, "learning means being looked at", [...] and all the feelings that may be involved in that look. [...]. (D20)

Unlike previous intrapersonal relationship, which is the subject's ability to relate with yourself, towards yourself, interpersonal relationship is understood as the ability that a person develops to understand and get along with others, according to Gardner (2001), Goleman (2012) and Lettnin (2013), as well said D1 and D19:

This profession routinely deals with relationships between people, [...], then there is no way to separate the emotions and feelings, they are present at all times. (D1); Affection [...] is a demonstration of feelings [...] if you are good about yourself you will you relate well with others. When you do not well you are under a certain pressure, I understand that the person acts in a different way [...] do not know if the word is rude, but not as nice as it would normally. (D19)

Although they are different, are closely interlinked, as well really know one personal needs to be able to deal well with others. To achieve this affective education, according Stobäus \& Mosquera (2008), you must, first, have good/realistic self-knowledge as teacher, allowing time to examine your life in the direction that aims to get the sense that it gives to your existence and a message that intends to disseminate among your students. Should also consider different views from them, be able to hear and understand each other, respecting him/her as an independent, unique and unfinished person. Social spaces create opportunities to have a positive/realistic relationship with others allows more openness to diversity, facing a living on a multiple and plural world.

These relationships (intrapersonal and interpersonal) are very important, also highlighted by D20, which stresses that must be worked from and greater emphasis on Basic Education, according to their experience:

A sample project, which works with the feelings, conducted at Children's Education, entitled "The feeling heart" which aims to work on personal and interpersonal relationships, highlighting the importance of good connivance, redeeming values, perceiving and reflecting on emotions, feelings and different ways to manifest them. (D20)

The psychologist Goleman (2012) considers the emotional intelligence as most responsible for the success or failure of people, during early human development. Most situations in life and work are permeated by relationships, so people with some qualities of "good" human relationships, as affability, gentleness and understanding, are more likely to succeed.

The teacher, most likely to be successful, according to Biddle, Good \& Goodson (2000), would be the one with better interpersonal relationships, and prioritizes their pedagogical processes in a more affective education.

According Dohms \& Stobäus (2010), the good/positive relationships between teachers and students are essential to create a healthy learning environment. When poorly handled, can be the main causes of learning problems, resulting in feelings of injustice, devaluation of self-image and self-esteem.

Kupfer (2003) states that there are cultural clashes in everyday relationships that hinder the learning outcomes and therefore stimulate reactions such as apathy, lack of discipline and aggressiveness. Thus, it is impossible to separate the intellectual life of the affective life.

According to Maturana \& Rezepka (2000), the field of coexistence presupposes an emotional basis and defines human relationships. So, how warns D3:

You can not create a barrier between the student and your person (as teacher). I think that's where the feeling, affection, enter in this sense to break this barrier, to make accessible to the student.

But, according to D16, this is not an easy task: 
I believe that by many teachers, there is still a great distance to their students, this makes little feeling may exist between student-teacher. [...] I believe that the teacher should seek to approach the student affective way, trying to understand the feelings externalized by the students, because in this way is be able to understand a lot of the actions of their learners.

Galvão (2003: p. 77) states that "emotion is nourished by the effect it has on the other" and that the success of a teacher in their pedagogical tasks is related, in most cases, the environment that he creates.

Accordingly to D5 and D11:

The affectivity as something you earn, and you create a bond with each other, [...] and that generates this sense of commitment to each other [...]. (D5); Personally I am very affectionate, which is reflected in the way I interact with people who are around me. Affectivity is interacting with people. (D11)

As says Lettnin (2013), generally the fact of not knowing and not customize to meet the needs and individual characteristics of the subjects makes school environments permeated with unease, both for neglecting this premise that reinforces the failure of those involved, encouraging low self-esteem, low self-image, and aggression. Therefore, the environment or the context in which they establish the most healthy human relationships, it becomes essential to know yourself well and good (re)meet each other, to understand their feelings, their representations, their particularities.

According to Jesus (2004), children, teenagers and adults, because of an inadequate process, are sicker institutions and their representatives, as the malaise can be generated by a lack of capacity, resiliency, use of coping strategies by subject to front requirements are imposed. To best experience this everyday, no need of the subject widely known their emotions and (re)actions, to further develop their skills to enhance the (intra and inter) personal and social well-being.

In this sense, according to Alzina (2010), one should maximize the constructive behaviors and reduce the destructive, such as: violence, angst, anxiety, stress, depression, among others. The improvement in better interpersonal relationships is found as one of the suggested to increase happiness, as the investigation consulted by the author elements.

Perhaps this is why it is worth highlighting the effort expended by D15, evidenced by the following statement: "in general, I feel rejected, I have good relationship with the students and I try to have it".

According Lettnin, Mendes, Dohms \& Stobäus (2013), school life may generate great impact on self-esteem of young people, because the educational environment will bring more external interference due to extended interpersonal relations, with repercussions not always controllable only in school.

Recalling, the category Affectivity in Interpersonal Relations in the educational setting records both elements on the way that teachers sighted affectivity and feelings in the educational environment, to serve as a qualitative tool to develop affection and feelings in this context.

Another category that emerged from the analysis of the responses was 5) Affectivity and professional qualification, which describes the continuous training either through workshops, projects, plans or moments of with specific skills professionals.

In the study of Mendes, Dohms, Zacharias, Lettnin, Mosquera \& Stobäus (2011), Professional Qualification category had already been cited as understood in the sense of continuing education, and to explain it, sought support in the study by Freund (2009), which has listed some important aspects to be considered regarding the professional qualification, such as: teachers do not let themselves be dominated by routine, keeping always open to exchange with colleagues and theoretical knowledge; experience and recreate new situations favorable to themselves and students; seek to answer the questions that arise in practice through continuing training and maintain successful strategies for teaching.

Sachs (2009: p. 116) emphasizes the need for teachers, as well as any professional, upgrade their skills and knowledge, and in the case of teaching pedagogical skills and knowledge related to content, referring to the continuing professional development, emphasizing that "it is important as a means to maintain and sustain a competent teaching profession".

Enricone (2005) believes that Continuing Education, pedagogically, turns to the improvement of soft skills, strengthening general education, teaching the subject to learn a continuous due to professional and personal needs.

Portal (2007: p. 287) also pointed out the possibility of Universities invest: 
In building a "truly comprehensive" educational culture that recognizes the inseparability of body, mind, heart and spirit; understanding that the University should favor spaces for discussion and knowledge construction, to enhance the awareness of teachers and students about the importance and need for investment in constitutive dimensions $B E$.

A being more professional, emotional, relational and spiritual, expresses the author, comes to meet that concern teachers surveyed, who in their speeches reveal the lack of investment in qualifying, addressing the theme of affectivity:

Perform dynamic differentiated with qualified professionals to discuss aspects related to affective with the group of teachers (D8); Work with the teacher so that he realizes the students and the context differently [...]. If you are not there for the initial training, then by continuing education (D9); Working over the feelings of the faculty and students [...]. Courses, dynamics, opportunities to deal with it more directly. (D18)

This lack of qualification in relation to affection/feelings may reflect the processes of teaching and learning. Following the analysis of the speeches, named category 6) Affection as a facilitating/disturbing of learning describes how teachers perceive the importance of their feelings in an educational context. As the quote from D7:

The feeling itself is accompanied by neurotransmitters and hormones that boost or block the brainpower, perception, memory.

Casassus (2009: p. 204) presents important concepts and research results about the influence of emotions in Education, stating that "learning depends mainly on the type of relationships established at school and in class", bringing also the variable that more influence on differences in learning was the emotional climate of the classroom, which comes with three others: the bond between teacher and students, the bond between the students and the atmosphere that emerges from these first variables. These elements, concludes the researcher (p. 205), "the emotions should be one of the purposes of education", due to its hugely important role for learning.

Many of the teachers interviewed have realized the influence of feelings in the educational process, as they may facilitate or disrupt learning, for example in the speeches:

The feelings [...] are fundamental [...] for learning. Only learn in relation to the other. (D20); If you feel angry to a teacher [...] you cannot approach him/her [...]. (D3); Break this dichotomy, that reason and emotion are separate, and begin to understand that they need to be together, we shall have the commitment to learning, affectivity is bond of love and love is the bond of responsibility. (D5)

According to Mora (2013: p. 66), feelings can be a food or an enemy of learning, as they are the foundations that support the processes of learning and memory:

The ideas, which are atoms of thought, which are elaborated in the neuronal circuits of the association areas of the cerebral cortex, are already imbued with meaning is pleasure or pain or a wide palette of emotional colors that make up the human world.

Also adds that the relation emotion-cognition is indissoluble binomial because the concepts developed in the brain are not as "neutral” emotion unlike are impregnated by it.

In Education Goleman (2012: p. 117) says that the flow experiences would more naturally attract students to school. Flow he defines as “the achievement of mastery in any craft or body of knowledge". The psychologist says that the school should be used for an area of spontaneous interest for the child, and encourage him/her to deepen it in higher levels until the flow in learning. Consequently, the child would feel from that positive and successful experience, and will face new challenges in other areas. Also adds that the quest flow is through learning (p. 117) "a more human, natural and probably most effective way to enlist the emotions in the service of education".

Teachers also mentioned that the good feelings/affectivity and it's improvement depend on how teachers are identified with their profession, which led to the category called 7) Affectivity for identification with the profession.

Teachers declare their professional identification when they give meaning to their work, showing love for the job, responsibility and motivation to teach: 
I'm in the mischievous talk about it because I am passionate for Education. Passion, a lot of passion! I'm always very happy in my work as an educator, even if you have many things to solve. I think the classroom gives us a great pleasure. (D2); The pleasure of the educator is to be in the classroom, I see now that what keeps me as a teacher, really, that's what I like to do. [...] At the time I also feel happy in the classroom, I try also the student realizes this joy, it also motivates with it and seek learning. (D9); We have to feel, first, love for Education. Because you will not be a teacher these days if you do not like it. (D19)

Ball \& Goodson (1985: p. 18) consider that "the ways in which teachers achieve, maintain, and develop their identity, their sense of self, in and through a career, are of vital significance in understanding the actions and commitments of teachers in their work".

Freund's (2009) study revealed that teachers take pride in the profession, feeling happy to be "at the service" of another, which reveals the identification with the profession, also may generate malaise and/or teacher welfare.

In the analyzed statements appears another elements at category 8) Affectivity related to Health and Education, which deals with the good feelings of affectivity or as contributors to the health of the persons (teachers, students), through a more positive learning environment, evidenced in these statements:

Affectivity is feeling good. (D12); As a determining factor in life, because according to the feelings govern is that our actions. If I feel good and have positive reactions if I feel bad, negative [...]. I believe we need to reeducate our feelings and know initially deal with them, identifying them and acknowledging that occur when administering them. (D18)

Another way to understand the affection and feelings directed Health in an educational context, in the narrower sense, it would be:

I understand as well [...] teacher first, reduce your workload. Second, increase the chances of having a better quality of life [...]. If the teacher is satisfied, the student is satisfied, the affectivity of both will be a considerable improvement. [...] The structure of her work is fundamental. (D19); I think a very broad sense, should provide an environment in which the teacher can rescue and care for your health (physical, emotional, ...). (D15).

The concept of health, in the twentieth century, was understood as the absence of disease but has changed effectively in the twenty-first century as a more holistic view, better understanding the health of subjects, considering the physical, psychological, social and spiritual dimensions.

This more comprehensive concept had already been expressed by the World Health Organization (WHO, 2010) in 1946, setting the Health as the state of complete physical, mental, and social well-being, adding the 1999 resolution, the spiritual aspect, as stated Salum (2012).

Despite the evolution of the concept of Health, Conceição (1994) criticizes the static conceptualization in relation to the "state of complete well-being", which does not serve to define health in daily actions. In this sense, Lettnin (2013: p. 39), interpreting these ideas of Conceição, believes that the dynamics of practical reality, the interaction of each person with their living environment will set your health, since "this interaction permanent, the influence of the environment on the actions each person can be positive in maintaining your health or not, posing a risk to your life".

The concept of health advocated by Conceição (1994: p. 5) must contain:

The performance of the front subject to imbalances and conflicts that arise throughout life, showing the best state of physical vitality, mental and social in search of solutions. Being healthy means being permanently active in the environment in which he lives, maintaining, modifying, creating everything in accordance with their aspirations for a better life-personal and community health.

Thus, as Conceição (1994), Jesus (2004) and Lettnin (2013), people become sick in environments where their capabilities are inferior to solve/mitigate the imbalances and conflicts from the permanent interrelationship between human and practical reality. According to Lettnin (2013), the concept of health defined by Conceição underscores the importance of the process, because health will be evaluated through the action of the subject, ie, how educators will face situations in order to seek a balance all these aspects of life.

This is how teachers understand the role of feelings or affectivity in Education, in order to minimize conflicts 
arising from relationships, creating a more positive and healthy environment that motivates those involved in the educational process.

This concept can be monitored in the following two speeches:

I try to increase the stability of affection and give much importance to the determination of my general condition, seeking the sensation of feeling good about myself and others. (D7); We feel good, that you forget you're a headache and continue with that work. [...] I think this is a feature to keep my cool, healthy relationship with students. [...] We have sometimes a little more tired, because the workload is large. (D10)

Another variable that is directly related to the health welfare is described by Diener (2000: p. 34) as Subjective Well-Being, that is, when "they are many positive and fewer negative emotions when they are engaged in interesting activities when they experience many pleasures and few pains, and when they are satisfied with their lives".

Soon, university teachers expressed their welfare while making a positive assessment of situations faced in the educational context, such as these speeches:

Rare occasions I had problems. I notice that my math classes even though they have a very cool climate, [...], they always rave in that sense. [...] Have to learn to deal with that student to an adverse situation does not become a thing out of control [...]. I say that I have tantrums every three years when the teacher notes that thing is ugly [...], there is need to stop [...]. A rule is very cool, I am very happy to teach and this is common (D10); To improve the affectivity in the educational context, it is necessary [...] to create the conditions of possibility for teachers to do their work, increase their self-esteem, value it in school processes and reduce your daily stress load, investing in times of training, reflection, recreation and health. (D20).

Given all the above categories, we can think in terms of an effective Health Education, pointed from the Education to Health, and a Education to Health, pointed from the perspective of the Health sector in direction to Education, both improving the development of healthy feelings and affectivity.

\section{Final Considerations}

From the results, it is possible to better understand the affection/feelings of university teachers is, first, directed to the Personal Aspects [1) Feelings/emotions in teaching; 2) Behavioral expression of feelings/emotions; 3) Self-concept in the environment educational, and 7) Affectivity for identification with the profession], second, focused on Social Aspects [4) Affectivity in interpersonal relations in the educational environment; 6) Affectivity as a facilitator/disturbing learning, and 8) Affectivity related to Health and Education and], finally, the Institutional Aspects [5) Affectivity in professional qualification], which, in general, makes us understand that, for the teachers interviewed, develop positive affectivity is very important in the educational context and depends on the individual formation, so it can be used positively in this environment as a tool for improving learning (interpersonal relationships) in a permeate of affection environment to allow reflection on the health of those involved, to modify it more positively.

As pointed out by the interviewed participants, the demand is to institute actions aimed at not only improving the professional , but also the personal aspects, dealing with cross-cutting themes, getting to know the context in which they operate, such as subsidies to create good and healthy links with colleagues and students.

Thus, it is understood that teachers and education managers need appropriate knowledge of Neuroscience and Emotional Education, in order to use them in their teaching and personal practice, seeking a better climate of classroom, a better relationship between them and their students, and, consequently, a better student learning, as well as in your own personal life, because many times the teacher is a real mentor, an example to be followed by others (their students, their colleagues, their family, the community in which it is inserted and active).

\section{References}

Alzina, R. B. (2010). Educación emocional y bienestar (6th ed.) Madrid: Wolters Kluwer.

André, C., \& Lelord, F. (2000). A auto-estima. Aprender a gostar de si para melhor viver com os outros. Lisboa: Editorial Presença.

Araújo, U. F. (2003). A dimensão afetiva da psique humana e a educação em valores. In: V. A. Arantes (Ed.), Afetividade na escola: Alternativas teóricas e práticas. São Paulo: Summus. 
Assis, S. G. et al. (2003). A representação social do ser adolescente: Um passo decisivo na promoção da saúde. Ciência \& Saúde Coletiva, Rio de Janeiro, 8, 669-680.

Ball, S. J., \& Goodson, I. F., Eds. (1985). Teachers’ Lives and Careers. Lewes: Falmer.

Biddle, B. J., Good, T. L., \& Goodson, I. F. (2000). La enseñanza y los profesores: La profesión de enseñar. Barcelona: Paidós.

Casassus, J. (2009). Fundamentos da educação emocional. Brasília: UNESCO/Líberlivro Editora.

Conceição, J. A. N. (1994). Saúde escolar: A criança, a vida e a escola. São Paulo: Sarvier.

Damásio, A. (2004). Em busca de Espinoza: prazer e dor na ciência dos sentimentos. São Paulo: Companhia das Letras (Original Looking for Spinoza: Joy, Sorrow, and the Feeling Brain. Orlando: Hancourt Books, 2003).

Damásio, A. (2012). O erro de Descartes: emoção, razão e o cérebro humano (3rd ed.) São Paulo: Companhia das Letras, 2012 (Original Descartes’ Error: Emotion, Reason and the Human Brain. London: Vintage, 2006).

Darwin, C. (2000). A Expressão das Emoções no Homem e nos Animais. São Paulo: Cia das Letras. (Original: The Expression of the Emotions in Man and Animals. London: John Murrey.)

Diener, E. (2000). Subjective Well-Being: The Science of Happiness and Proposal for a National Index. American Psychologist, 55, 34-43. http://dx.doi.org/10.1037/0003-066X.55.1.34

Dohms, K., \& Stobäus, C. D. (2010). A influência do mal-estar docente no processo de aprendizagem discente. In V. Mostra de Pesquisa da Pós-graduação, Porto Alegre/RS. Anais eletrônicos... Porto Alegre-RS: PUCRS. http://www.pucrs.br/edipucrs/vmostra/v mostra pdf/educacao/82742-karina pacheco dohms.pdf

Ekman, P. (2011). A linguagem das emoções: Revolucione sua comunicação e seus relacionamentos reconhecendo todas as expressões das pessoas ao redor. São Paulo: Lua de Papel. (Original: Emotions Revealed. New York: Henry Holt and Company.)

Enricone, D., \& Grillo, M. (2005). Educação superior: Vivências e visão de futuro. Porto Alegre: EDIPUCRS.

Freund, C. S. (2009). Sonhando com o ideal, pisando no real, fazendo o possível: trabalho e vida de professores comprometidos com a profissão docente a mais de trinta anos. Dissertação, Rio de Janeiro: Faculdade de Educação. http://www2.dbd.puc-rio.br/pergamum/biblioteca/php/mostrateses.php?open=1\&arqtese=0710355_09_Indice.html

Galvão, I. (2003). Expressividade e emoções segundo a perspectiva de Wallon. In V. A. Arantes (Org.), Afetividade na escola: Alternativas teóricas e práticas. São Paulo: Summus.

Gardner, H. (2001). Inteligência um conceito reformulado: O criador da teoria de inteligências múltiplas explica e expande suas idéias com enfoque no século XXI. Rio de Janeiro: Objetiva. (Original: Intelligence Reframed. New York: Basic Books.)

Goleman, D. (2012). Inteligência emocional: A teoria revolucionária que define o que é ser inteligente. Rio de Janeiro: Objetiva. (Original: Emotional Intelligence. New York: Bantam Books.)

Goñi, E., \& Fernández, A. (2009). El Autoconcepto. In A. G. Grandmontagne (Coord.), El autoconcepto físico. Madrid: Ediciones Pirámide.

Heller, A. (1987). Teoría de los sentimientos. Barcelona: Editora Fontamara. (Original: A Theory of Feelings. Assen: Van Gurcun.)

Jesus, S. N. (2004). Psicologia da Educação. Coimbra: Quarteto.

Kupfer, M. C. M. (2003). Afetividade e cognição: Uma dicotomia em discussão. In V. A. Arantes (Org.), Afetividade na escola: Alternativas teóricas e práticas. São Paulo: Summus.

Lettnin, C. (2013). (Des)seriação da Educação Física no Ensino Médio como proposta de contribuição a Saúde: Visão de alunos e professores. Tese (Doutorado em Educação), Rio de Janeiro: Faculdade de Educação.

Lettnin, C. C., Mendes, A. R., Dohms, K. P., \& Stobäus, C. D. (2013). Avaliação dos níveis de autoestima de adolescentes portugueses e brasileiros. Proceedings of the II Congresso Íbero-Americano/III Congresso Luso-Brasileiro de Psicologia da Saúde. Atas... Faro: Universidade do Algarve, 1-21.

Luria, A. R. (1980). Fundamentos de Neuropsicologia. São Paulo/Rio de Janeiro: EDUSP/Livros Técnicos e Científicos. (Original: The Working Brain. London: Penguin Books.)

Maslow, A. (1987). Motivation and Personality. New York: Harper \& Row.

Maturana, H., \& Rezepka, S. N. (2000). Formação humana e capacitação. Petrópolis, Rio de Janeiro: Vozes.

Mendes, A. R., Dohms, K. P., Lettnin, C. C., Zacharias, J., Mosquera, J. M. \& Stobäus, C. D. (2012). Autoimagem, Autoestima e Autoconceito: Contribuições pessoais e profissionais na docência. Caxias do Sul: IX Anped Sul—Seminário de Pesquisa em Educação da região Sul, 1-13.

Mendes, A. R., Dohms, K. P., Zacharias, J., Lettnin, C., Mosquera, J. J. M., \& Stobäus, C. D. (2011). Bem-estar docente: 
Indicadores e subsídios. Proceedings of the II Congresso Luso-Brasileiro de Psicologia da Saúde e I Congresso Ibero-Americano de Psicologia da Saúde, São Bernardo do Campo. Transformações socioculturais e promoção de saúde. Anais... São Bernardo do Campo: Universidade Metodista de São Paulo, 1-34.

Monteiro, R. F., Azevedo, L. F., Sobreiro, R. T., \& Constantino, P. (2012). Autoestima e resiliência dos adolescentes da margem da linha: Redes de apoio social, como fator de proteção. Perspectivas Online: Biologia \& Saúde, 4, 41-55.

Mora, F. (2013) Neuroeducación: Solo se pude aprender aquello que se ama. Madrid: Alianza.

Morais, R. (1998). Uma experiência de pesquisa coletiva: introdução à análise de conteúdo. In M. C. Grillo, \& M. F. De Medeiros (Orgs.), A construção do conhecimento e sua mediação metodológica. Porto Alegre: EDIPUCRS.

Mosquera, J. J. M., \& Stobäus, C. D. (2006). Afetividade: A manifestação de sentimentos na Educação. Educação-PUCRS, 58(1), 123-133.

Mosquera, J. J. M., \& Stobäus, C. D. (2008). O professor, personalidade saudável e relações interpessoais: Por uma educação da afetividade. In D. Enricone (Ed.), Ser professor (6th ed.). Porto Alegre: EDIPUCRS.

Mosquera, J. J. M. (1978). O professor como pessoa. Porto Alegre: Sulina.

Organização Mundial da Saúde (OMS) (2010). Constituição da Organização Mundial da Saúde (OMS/WHO), 1946. http://www.direitoshumanos.usp.br/index.php/OMS-Organiza\%C3\%A7\%C3\%A3o-Mundial-da-Sa\%C3\%BAde/constituic ao-da-organizacao-mundial-da-saude-omswho.html.

Portal, L. L. F. (2007). Educação para inteireza: Um(re)descobrir-se. Educação, 285-296.

Rogers, C. R. (1997). Tornar-se pessoa. São Paulo: Martins Fontes. (Original: Becoming a Person. Oberlin: Oberlin College, 1954.)

Sachs, J. (2009). Aprender para melhorar ou melhorar a aprendizagem: O dilema do desenvolvimento profissional contínuo dos professores. In M. A. Flores, \& A. M. V. Simão (Org.), Aprendizagens e desenvolvimento profissional de professores: Contextos e perspectivas. Almada: Pedago.

Salum, T. (2012). O acompanhamento pré-natal. In: C. E. A. Durgante (Org.), Conectando ciência, saúde e espiritualidade. Porto Alegre: Francisco Spinelli.

Sbicigo, J. B., Bandeira, D. R., \& Dell’Aglio, D. D. (2010). Escala de Autestima de Rosenberg (EAR): Validade fatorial e consistência interna. Psico-USF, 3, 395-403. http://dx.doi.org/10.1590/S1413-82712010000300012

Schaie, K. W., \& Willis, S. L. (2003). Psicología de la Edad Adulta y la Vejez. Madrid: Pearson. (Original: Adult Development and Aging (2 ed.). Boston: Littlr \& Brown.)

Stobäus, C. D. (1983). Desempenho e auto-estima em jogadores profissionais e amadores de futebol. Análise de uma realidade e implicações educacionais. Dissertação (Mestrado em Educação), Porto Alegre: Faculdade de Educação da UFRGS.

Vygotsky, L. S. (1989). A formação social da mente (3rd ed.). São Paulo: Martins Fontes. (Original Thought and Language. (newly revised, translated, and edited by Alex Kozulin). Cambridge (Massachusetts): The M.l.T. Press, 1986). 
Scientific Research Publishing (SCIRP) is one of the largest Open Access journal publishers. It is currently publishing more than 200 open access, online, peer-reviewed journals covering a wide range of academic disciplines. SCIRP serves the worldwide academic communities and contributes to the progress and application of science with its publication.

Other selected journals from SCIRP are listed as below. Submit your manuscript to us via either submit@scirp.org or Online Submission Portal.
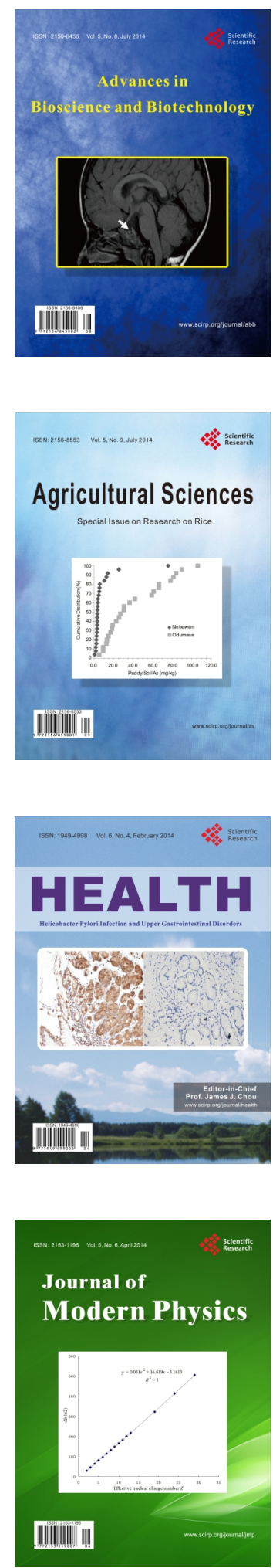
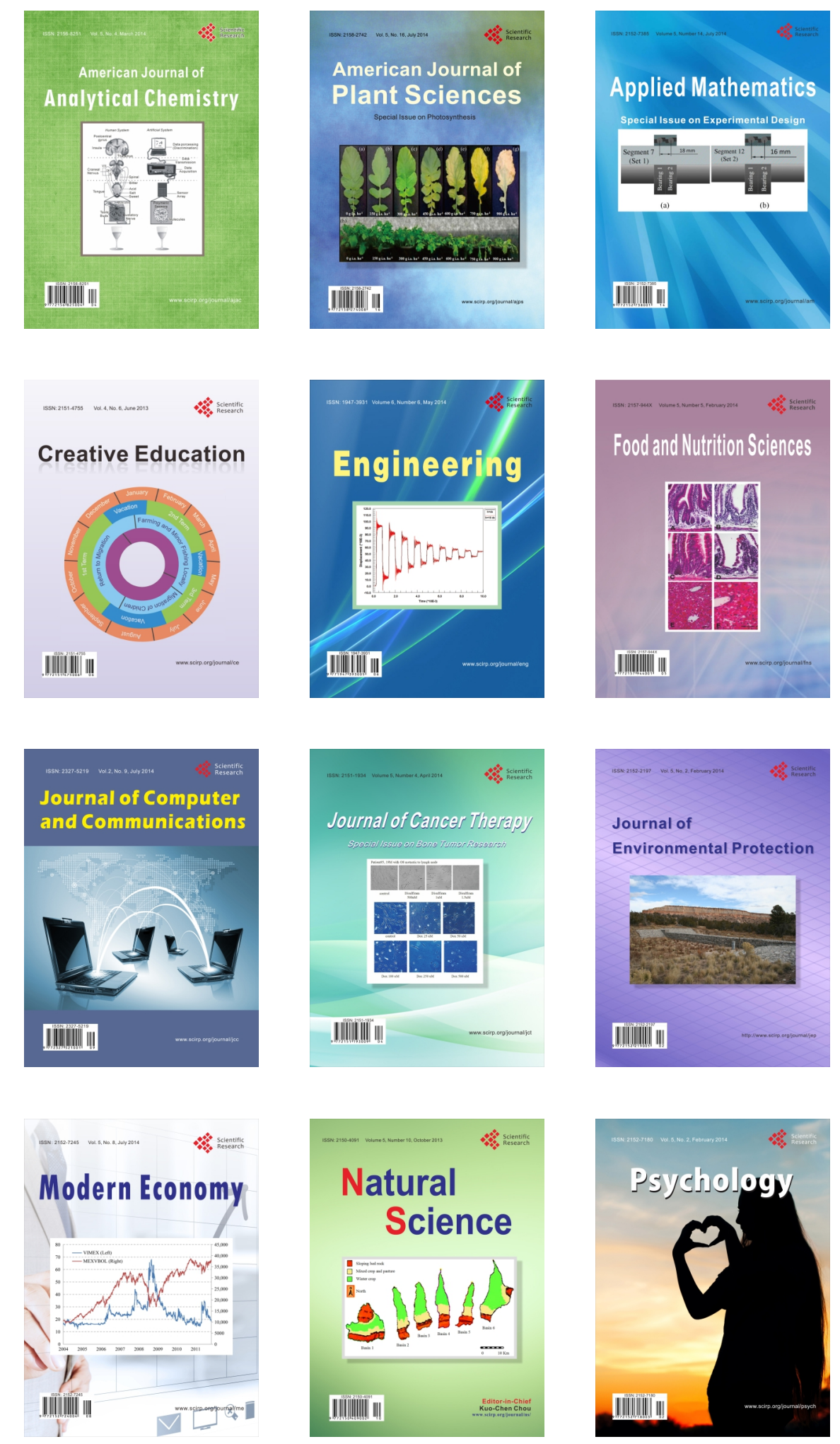